Acta vet. scand. 1976, 17, 83-100.

From the Department of Obstetrics and Gynaecology, the Department of Clinical Biochemistry and the Department of Anatomy and Histology, Veterinary College, Stockholm/Uppsala, Sweden.

\title{
INFLUENCE OF THAWING DILUENTS ON VITALITY, ACROSOME MORPHOLOGY, ULTRASTRUCTURE AND ENZYME RELEASE OF DEEP FROZEN BOAR SPERMATOZOA*
}

By

\author{
K. Larsson, S. Einarsson and L. Nicander
}

\begin{abstract}
LARSSON, K., S. EINARSSON and L. NICANDER: Influence of thawing diluents on vitality, acrosome morphology, ultrastructure and enzyme release of deep frozen boar spermatozoa. Acta vet. scand. 1976, $17,83-100$. - The present investigation was performed to study the effect of freezing and thawing on boar spermatozoa. Thirty-one ejaculates from four boars were investigated after thawing in three different thawing diluents (seminal plasma, OLEP, isotonic glucose solution).

From each ejaculate one sample of $1 \times 10^{9}$ spermatozoa was thawed in each of the thawing diluents. Each sample was examined in a thermoresistance test in which motility was stimulated with caffeine $30 \mathrm{~min}$. and $3 \mathrm{hrs}$. after thawing. Furthermore, acrosome morphology and ASAT release from the spermatozoa were investigated for each sample. One ejaculate from the two most frequently used boars was examined by electron microscopy after thawing in each of the thawing diluents.

Differences in the aspects studied appeared between isotonic glucose solution and the other two thawing diluents in the thermoresistance test, in the response to caffeine stimulation 3 hrs. after thawing and in the amount of ASAT released from the spermatozoa. The influence on the acrosome morphology varied between the thawing diluents, but the acrosomal alterations did not seem to be connected with the damage reflected by the thermoresistance test and by the measurement of extracellular ASAT activity.

The ultrastructural investigation showed that all spermatozoa examined had some degree of ultrastructural alteration as compared with freshly ejaculated boar spermatozoa treated in the same way. This alteration could not be related to any of the thawing diluents.

Of the various laboratory tests the thermoresistance test and the measurement of ASAT release are suggested to be sensitive indicators of sperm damage during freezing and thawing. These tests might be useful indicators of variations in sensitivity of spermatozoa to the freezing-thawing procedure.
\end{abstract}

deep frozen boar spermatozoa; thawing diluents; vitality; acrosome morphology; ultrastructure; enzyme release.

* This study was supported by grants from Svensk Husdjursskötsel, Hållsta and the Swedish Council for Forestry and Agricultural Research. 
Various laboratory tests have been utilized to estimate the quality of frozen-thawed boar spermatozoa. These tests have contributed to a rapid progress concerning the choice of diluents and of additives. The relationship between different laboratory tests was studied by Graham \& Crabo (1972).

Initial sperm motility has been considered as the major criterion of post thawing sperm quality. However, later studies indicate that estimation of motility at regular intervals during in vitro storage at $37^{\circ} \mathrm{C}$, the so-called "thermoresistance test", is most probably a better indicator of sperm quality (Einarsson et al. 1972, 1974, Boehnke et al. 1974, Westendorf et al. 1975).

The decrease in motility during the thermoresistance test could be due to a continuous dieing off of spermatozoa and/or merely reflect an anabiosis of the frozen-thawed spermatozoa. To distinguish between these two possibilities the spermatozoal response to caffeine stimulation could be used. Garbers et al. (1973) found that phosphodiesterase inhibitors stimulated motility and respiratory activity of ejaculated porcine spermatiozoa.

Abnormalities of the acrosome morphology of boar spermatozoa have been associated with sterility (Bane 1961, Bane \& Nicander 1966) or with subfentility (Andersen 1974) when appearing in freshly ejaculated spermatozoa. As a laboratory test for stored fresh or frozen boar spermatozoa, acrosome morphology has been utilized in a number of investigations (cf. Pursel et al. 1972, 1973, Hillman \& Treu 1973, Boehnke et al., Romeny et al. 1974).

The ultrastructure of frozen-thawed boar spermatozoa has been studied with transmission electron microscopy by Healey (1969) and with scanning electron microscopy by Yasuda \& Tanimura (1974). However in these investigations glycerol levels in the pre-freezing diluents exceeded those known to be detrimental to the fertilizing capacity of boar semen (Polge 1956, Crabo et al. 1971, Wilmut \& Polge 1974). Thus there is so far no information available concerning the ultrastructure of potentially fertile frozen-thawed boar spermatozoa.

Release of aspartate aminotransferase (ASAT, GOT, EC 2.6.1.1.) from the spermatozoa during freezing and thawing has been used as an indicator of cell damage in a number of investigations (Graham \& Pace 1967, Brown et al. 1971, Crabo \& Graham 1972). This analysis has also been utilized to evaluate the 
effects of buffers and glycerol during freezing and thawing of boar spermatozoa (Crabo et al. 1971, 1972).

For practical purpose it is of great importance to investigate which of the above mentioned laboratory tests could be used for further improvement of freezing methods.

The aim of this investigation was to study the influence of three thawing diluents - boar seminal plasma, OLEP and isotonic glucose solution - on vitality, acrosome morphology, ultrastructure and enzyme release of deep frozen boar spermatozoa. In addition an attempt was made to evaluate the suitability of the aforementioned laboratory tests as criteria of sperm quality.

\section{MATERIAL AND METHODS}

The study comprises laboratory investigations of 31 ejaculates from four boars. Two of them $(172,966)$ were of Swedish Landrace and two of them $(388,1164)$ of Swedish Yorkshire breed. The fertility of the boars was previously tested at artificial inseminations with fresh semen or at natural service and found to be good. Before and during the deep freezing trials their semen quality was examined and found to be normal (cf. Holst 1949, Bane 1961). The number of ejaculates investigated varied between the boars and was dependent on the frequency at which they were used in subsequent fertility tests. From each of the boars the following numbers of ejaculates were investigated: 172: 10 ejaculates; 966: six ejaculates; 388: nine ejaculates; 1164: six ejaculates. As a routine, semen was collected and frozen once a week from each of the boars. Freezing was performed according to the method of Crabo \& Einarsson (1971) as recently described by Larsson \& Einarsson (1976). For the ejaculates investigated the storage time in liquid nitrogen ranged from six weeks to seven months.

\section{Experimental procedure}

All laboratory tests were split ejaculate tests with comparison of three thawing diluents, A: boar seminal plasma, C: OLEP and D: isotonic glucose solution. In the sequel the term "sample" refers to a certain number of spermatozoa from one ejaculate thawed in one of the three thawing diluents, i.e. from one ejaculate three samples were thawed, one sample in each of the 
thawing diluents. To ensure objectivity throughout the tests all samples were coded and the identity of each sample remained unknown to the investigator.

\section{Thawing diluents and thawing procedure}

The seminal plasma used was the sperm-poor fractions of ejaculates collected for freezing. These fractions were added with benzyl penicillin immediately after collection and then centrifuged for $20 \mathrm{~min}$. at $3200 \times \mathrm{g}$ to eliminate spermatozoa. Until used the seminal plasma was stored at $-20^{\circ} \mathrm{C}$. Spermatozoal sample and seminal plasma always originated from the same boar. OLEP was prepared and stored as described by Larsson \& Einarsson (1976). The isotonic glucose solution was a commercial $5.5 \%$ preparation (ACO, Stockholm).

The same thawing procedure was followed for all thawing diluents. For each sample $1 \times 10^{9}$ spermatozoa were thawed in $16-18 \mathrm{ml}$ of thawing diluent. The volume of frozen spermatozoa added averaged $2-4 \mathrm{ml}$. The average sperm concentration in thawed samples was thus $0.05 \times 10^{9}$ spermatozoa per ml.

Thawing was done in $50 \mathrm{ml}$ glass vessels in a hot water bath. The temperature in the thawing diluent was kept at $35^{\circ} \mathrm{C}$. Pellets were dumped into the thawing diluent in portions of 10 until a sufficient number of spermatozoa were thawed.

\section{Laboratory tests}

Thermoresis t a c e test. Immediately after thawing of each sample the percentage of progressively motile spermatozoa was estimated under a phase-contrast microscope. The samples were then stored in the closed thawing vessels at a temperature of $37^{\circ} \mathrm{C}$. After storage for $30 \mathrm{~min}$. and $3 \mathrm{hrs}$., respectively, the percentage of motile spermatozoa was again estimated. On these occasions motility was estimated with and without stimulation with caffeine according to Garbers et al. (1973). For caffeine stimulation small parts of each sample were withdrawn into plastic tubes and incubated for $1-2 \mathrm{~min}$. with a $2 \mathrm{mM}$ concentration of caffeine.

Acrosome morphology. The acrosome morphology was investigated in two different ways and by two persons independently. Immediately after thawing, a small portion of each 
sample was fixed in formol-saline solution according to Hancock (1957). In addition to this a thin smear of unfixed semen was prepared and allowed to dry in air on clean microscopic slides. The smears were stained according to Bryan (1970). The acrosome morphology of formol-saline-fixed spermatozoa was estimated by differential count of 200 cells under phase-contrast microscopy at $900 \times$ magnification. The acrosome morphology of Bryan-stained smears was estimated with bright-field microscopy at $1000 \times$ magnification by differential count of 200 cells from each smear. In the differential counts the acrosomes were divided into three groups according to the following morphological criteria:

NA normal acrosomes with a distinct and even apical ridge and without any sign of swelling.

DA damaged acrosomes. This group included a number of alterations in the acrosomes but without loss of acrosomal substance. The two most common types appearing in this group were swollen acrosomes and acrosomes with an uneven anterior border of the acrosome folding over the nucleus.

SDA severely damaged acrosomes. The apical ridge was disintegrated with an apparent loss of acrosomal substance. Only the equatorial segment seemed in most cases to be unaltered. The few spermatozoa that had lost the entire acrosome were also included in this group.

Ultrastructural investigation. One ejaculate from each of boars 172 and 388 was randomly selected for electron microscopy in addition to the other tests performed. Five $\mathrm{ml}$ portions of each thawed sample were fixed immediately after thawing for $30 \mathrm{~min}$. in an equal volume of a $2 \%$ osmium tetroxide solution according to Millonig. Fixed spermatozoa were centrifuged for $10 \mathrm{~min}$. at $156 \times \mathrm{g}$. The sediments following centrifugation were embedded in Epon. Thin sections were cut with diamond knives, stained with uranyl acetate and examined in a Philips EM 201 electron microscope. Epididymal and freshly collected spermatozoa from other boars, treated in the same way, were available for comparison.

A S A T r e l e a s e. Immediately after thawing, $10 \mathrm{ml}$ of each sample was centrifuged for $15 \mathrm{~min}$. at $3200 \times \mathrm{g}$. From the supernatant of each centrifuge tube $5 \mathrm{ml}$ was pipetted into a plastic tube and stored at $-20^{\circ} \mathrm{C}$ until assayed. ASAT was deter- 
mined according to the kinetic method for determination of ASAT in blood recommended by the Committee on Enzymes of the Scandinavian Society for Clinical Chemistry and Clinical Physiology (1974). Commercially available reagents were utilized (AB KABI, Stockholm). Determination of activity was done with a LKB 8600 Reaction Rate Analyzer. Two determinations of activity were made from each sample, the mean values being used for calculation of ASAT activity per $1 \times 10^{9}$ spermatozoa. Sperm-free samples from each batch of seminal plasma utilized as thawing diluent were analysed in the same way and the resulting values were utilized for correction of background activity.

\section{STATISTICAL ANALYSES}

Conventional statistical methods were used to test differences in the results of the laboratory tests (Snedecor 1966). Differences within ejaculates between thawing diluents were tested with a paired $t$-test. The same method was utilized to test differences between the estimations of acrosome morphology within samples.

T a ble 1A. Initial post thawing sperm motility (mean \pm s.e.m.) and motility after storage for $30 \mathrm{~min}$. and $3 \mathrm{hrs}$. of deep frozen spermatozoa from four boars thawed in three diluents with and without caffeine stimulation.

\begin{tabular}{|c|c|c|c|c|c|c|}
\hline \multirow[t]{3}{*}{ Boar } & \multirow{3}{*}{$\begin{array}{l}\text { Thawing } \\
\text { diluent }\end{array}$} & \multirow{3}{*}{$\begin{array}{c}\text { Initial } \\
\text { motility }\end{array}$} & \multicolumn{4}{|c|}{ Storage time at $37^{\circ} \mathrm{C}$} \\
\hline & & & \multicolumn{2}{|c|}{30 min. } & \multicolumn{2}{|c|}{$3 \mathrm{hrs}}$. \\
\hline & & & without $\mathrm{c}$. & with c. & without $c$. & with $\mathrm{c}$. \\
\hline 388 & $\mathbf{A}$ & $27 \pm 2.5$ & $31 \pm 1.8$ & $37 \pm 2.2$ & $11 \pm 2.1$ & $31 \pm 3.4$ \\
\hline 388 & C & $36 \pm 1.5$ & $38 \pm 1.2$ & $44 \pm 2.5$ & $16 \pm 2.7$ & $37 \pm 3.0$ \\
\hline 388 & D & $34 \pm 2.3$ & $29 \pm 3.3$ & $36 \pm 2.4$ & $1 \pm 0.7$ & $2 \pm 0.8$ \\
\hline 172 & $\mathbf{A}$ & $20 \pm 2.0$ & $21 \pm 3.6$ & $37 \pm 2.4$ & $13 \pm 1.7$ & $23 \pm 1.8$ \\
\hline 172 & C & $29 \pm 3.0$ & $33 \pm 2.4$ & $46 \pm 1.8$ & $11 \pm 1.6$ & $40 \pm 2.4$ \\
\hline 172 & D & $23 \pm 3.0$ & $15 \pm 3.5$ & $28 \pm 4.1$ & $0 \pm 0$ & $2 \pm 1.2$ \\
\hline 1164 & $\mathbf{A}$ & $30 \pm 2.2$ & $22 \pm 3.8$ & $38 \pm 2.0$ & $9 \pm 2.4$ & $26 \pm 4.0$ \\
\hline 1164 & C & $33 \pm 1.7$ & $33 \pm 3.3$ & $44 \pm 3.3$ & $6 \pm 1.5$ & $22 \pm 2.1$ \\
\hline 1164 & D & $34 \pm 2.0$ & $21 \pm 3.3$ & $27 \pm 4.1$ & $0 \pm 0.2$ & $3 \pm 0.8$ \\
\hline 966 & $\mathbf{A}$ & $26 \pm 3.5$ & $23 \pm 4.6$ & $38 \pm 4.4$ & $3 \pm 0.8$ & $18 \pm 6.9$ \\
\hline 966 & C & $30 \pm 2.6$ & $29 \pm 4.0$ & $43 \pm 3.1$ & $1 \pm 0.8$ & $25 \pm 5.5$ \\
\hline 966 & D & $31 \pm 2.4$ & $19 \pm 4.5$ & $30 \pm 6.1$ & $0 \pm 0.3$ & $2 \pm 0.7$ \\
\hline All & $\mathbf{A}$ & $25.8 \pm 1.4$ & $24.3 \pm 1.8$ & $37.5 \pm 1.4$ & $9.0 \pm 1.8$ & $24.5 \pm 2.0$ \\
\hline \multirow[t]{2}{*}{ boars } & C & $32.0 \pm 1.3$ & $33.3 \pm 1.4$ & $44.3 \pm 1.2$ & $8.5 \pm 1.6$ & $31.0 \pm 2.1$ \\
\hline & D & $30.5 \pm 1.5$ & $21.0 \pm 2.0$ & $30.3 \pm 2.2$ & $0.3 \pm 0.2$ & $2.3 \pm 0.5$ \\
\hline
\end{tabular}


The degree of significance is expressed as follows:

\begin{tabular}{|c|c|}
\hline $\begin{aligned} 0.05> & \mathrm{P}>0.01^{\star} \\
0.01> & \mathrm{P}>0.001^{\star *} \\
& \mathrm{P}<0.001^{\star \star *}\end{aligned}$ & $\begin{array}{l}\text { almost significant } \\
\text { significant } \\
\text { highly significant }\end{array}$ \\
\hline
\end{tabular}

\section{RESULTS}

Initial post thawing motility and thermoresistance test

The initial post thawing motility, the results of the thermoresistance test and the response to caffeine stimulation during the thermoresistance test are summarized in Table $1 \mathrm{~A}$. Table $1 \mathrm{~B}$ presents the results of the statistical analyses of differences.

The effect of the thawing diluents on initial post thawing motility was limited. The only apparent effect was comparatively lower percentages of motile spermatozoa in samples thawed in seminal plasma.

The thermoresistance test disclosed clear differences in the effects of the thawing diluents. The isotonic glucose solution was clearly inferior to seminal plasma and OLEP in maintaining the motility of the spermatozoa during storage at $37^{\circ} \mathrm{C}$. The decrease in motility was apparent already after 30 min., and after $3 \mathrm{hrs}$. of storage only few sperms were motile in samples thawed

T a b l e 1B. Results of statistical analyses of motility data presented in Table 1A. Interdiluent variation within ejaculates, symbols indicat-

ing level of significance as described in material and methods.

\begin{tabular}{|c|c|c|c|c|c|c|}
\hline \multirow[t]{2}{*}{ Boar } & \multirow[t]{2}{*}{ Comparison } & \multirow{2}{*}{$\begin{array}{c}\text { Initial } \\
\text { motility }\end{array}$} & \multicolumn{2}{|c|}{$30 \mathrm{~min}}$. & \multicolumn{2}{|c|}{$3 \mathrm{hrs}$. } \\
\hline & & & without c. & with $\mathrm{c}$. & without $\mathrm{c}$. & with $\mathrm{c}$. \\
\hline 388 & $A-C$ & $\star \star \star *$ & n.s. & n.s. & n.s. & * \\
\hline 388 & $\mathrm{C}-\mathrm{D}$ & n.s. & $\star$ & * * & $\star \star \star \star$ & $\star \star \star *$ \\
\hline 388 & $\mathbf{A}-\mathbf{D}$ & n.s. & n.s. & n.s. & $\star \star$ & 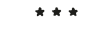 \\
\hline 172 & $A-C$ & * * & * * & $\star * \star *$ & n.s. & 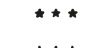 \\
\hline 172 & $\mathrm{C} \longrightarrow \mathrm{D}$ & ${ }^{*}$ & $\star \star *$ & ** & $\star \star \star *$ & *** \\
\hline 172 & $\mathbf{A}-\mathbf{D}$ & n.s. & n.s. & $\star$ & $\star \star \star *$ & 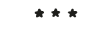 \\
\hline 1164 & $A-C$ & * & * * & * & n.s. & n.s. \\
\hline 1164 & $\mathrm{C}-\mathrm{D}$ & n.s. & * & * & * & $\star \star \star *$ \\
\hline 1164 & $A-D$ & n.s. & n.s. & n.s. & * * & $\star \star *$ \\
\hline 966 & $A-C$ & n.s. & n.s. & n.s. & n.s. & n.s. \\
\hline 966 & $\mathrm{C}-\mathrm{D}$ & n.s. & ${ }^{\star}$ & $\star$ & n.s. & $\star$ \\
\hline 966 & $\mathbf{A}-\mathbf{D}$ & $\star$ & n.s. & * & n.s. & n.s. \\
\hline All & $A-C$ & $\star \star \star *$ & *** & $\star \star \star *$ & n.s. & $* \star \star$ \\
\hline \multirow[t]{2}{*}{ boars } & $\mathrm{C}-\mathrm{D}$ & n.s. & $\star \star \star *$ & $\star \star \star *$ & 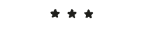 & 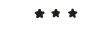 \\
\hline & $A-D$ & $\star \star$ & n.s. & $\star \star \star *$ & $\star \star * *$ & $\star \star \star *$ \\
\hline
\end{tabular}


T a ble 2A. Acrosome morphology of deep frozen spermatozoa from four boars after thawing in three diluents as estimated by phasecontrast microscopy (F.s.) or by light microscopy after staining with Bryan's tripple staining (B). Mean \pm s.e.m. values within boars and thawing diluents and level of significance of intermethod differences within samples.

\begin{tabular}{|c|c|c|c|c|c|c|}
\hline \multirow{2}{*}{$\begin{array}{l}\text { Thawing } \\
\text { diluent }\end{array}$} & \multirow{2}{*}{$\begin{array}{c}\% \\
\text { sperma- } \\
\text { tozoa } \\
\text { with }\end{array}$} & \multirow[t]{2}{*}{ Method } & \multicolumn{4}{|c|}{ Boar } \\
\hline & & & 388 & 172 & 1164 & 966 \\
\hline \multirow{2}{*}{$\begin{array}{l}\text { Seminal } \\
\text { plasma }\end{array}$} & NA & $\begin{array}{l}\text { F.s. } \\
\text { B. } \\
\text { diff. }\end{array}$ & $\begin{array}{r}13 \pm 1.5 \\
8 \pm 1.8\end{array}$ & $\begin{array}{c}11 \pm 1.7 \\
11 \pm 1.1 \\
\text { n.s. }\end{array}$ & $\begin{array}{r}9 \pm 1.6 \\
11 \pm 2.3 \\
\text { n.s. }\end{array}$ & $\begin{array}{c}11 \pm 2.5 \\
22 \pm 3.2\end{array}$ \\
\hline & SDA & $\begin{array}{l}\text { F.s. } \\
\text { B. } \\
\text { diff. }\end{array}$ & $\begin{array}{c}11 \pm 2.7 \\
22 \pm 2.3\end{array}$ & $\begin{array}{l}10 \pm 2.0 \\
25 \pm 3.0\end{array}$ & $\begin{array}{r}9 \pm 1.5 \\
19 \pm 1.5\end{array}$ & $\begin{array}{r}3 \pm 0.6 \\
16 \pm 1.6 \\
\star \star \star\end{array}$ \\
\hline \multirow{2}{*}{ OLEP } & NA & $\begin{array}{l}\text { F.s. } \\
\text { B. } \\
\text { diff. }\end{array}$ & $\begin{array}{c}8 \pm 0.8 \\
11 \pm 1.4 \\
\text { n.s. }\end{array}$ & $\begin{array}{r}4 \pm 0.7 \\
11 \pm 2.1 \\
\star \star \star\end{array}$ & $\begin{array}{c}4 \pm 1.0 \\
7 \pm 1.7 \\
\text { n.s. }\end{array}$ & $\begin{array}{r}4 \pm 1.4 \\
11 \pm 2.0 \\
\star \star\end{array}$ \\
\hline & SDA & $\begin{array}{l}\text { F.s. } \\
\text { B. } \\
\text { diff. }\end{array}$ & $\begin{array}{c}24 \pm 1.9 \\
26 \pm 2.1 \\
\text { n.s. }\end{array}$ & $\begin{array}{l}17 \pm 2.7 \\
27 \pm 2.8\end{array}$ & $\begin{array}{l}21 \pm 2.3 \\
25 \pm 1.8\end{array}$ & $\begin{array}{c}10 \pm 1.9 \\
22 \pm 2.6 \\
\star \star\end{array}$ \\
\hline \multirow{2}{*}{$\begin{array}{l}\text { Isotonic } \\
\text { glucose } \\
\text { solution }\end{array}$} & NA & $\begin{array}{l}\text { F.s. } \\
\text { B. } \\
\text { diff. }\end{array}$ & $\begin{array}{c}13 \pm 2.2 \\
14 \pm 2.2 \\
\text { n.s. }\end{array}$ & $\begin{array}{r}9 \pm 2.0 \\
15 \pm 2.4\end{array}$ & $\begin{array}{r}8 \pm 2.0 \\
15 \pm 1.7\end{array}$ & $\begin{array}{c}13 \pm 3.6 \\
21 \pm 3.0 \\
\text { n.s. }\end{array}$ \\
\hline & SDA & $\begin{array}{l}\text { F.s. } \\
\text { B. } \\
\text { diff. }\end{array}$ & $\begin{array}{c}25 \pm 3.9 \\
23 \pm 2.4 \\
\text { n.s. }\end{array}$ & $\begin{array}{c}19 \pm 2.7 \\
24 \pm 2.6 \\
\text { n.s. }\end{array}$ & $\begin{array}{c}22 \pm 4.1 \\
23 \pm 2.5 \\
\text { n.s. }\end{array}$ & $\begin{array}{c}10 \pm 2.9 \\
16 \pm 3.5 \\
\text { n.s. }\end{array}$ \\
\hline
\end{tabular}

in isotonic glucose solution. At this time the differences in motility between samples thawed in isotonic glucose solution and samples thawed in seminal plasma or in OLEP were significant or highly significant for three of the boars $(388,172,1164)$ and for the pooled material. In the ejaculates of boar 966, however, the motility 3 hrs. after thawing was poor in all samples regardless of thawing diluent.

Caffeine stimulation after 30 min.' storage at $37^{\circ} \mathrm{C}$ yielded maximum motility in samples thawed in seminal plasma or in OLEP. A stimulatory effect was seen in samples thawed in isotonic glucose solution. A similar tendency was observed after 3 hrs.' storage, although the effect on samples thawed in isotonic glucose solution was very poor, in many samples none. The re- 
T a b l e 2B. Summarized influence of thawing diluents on acrosome morphology (mean \pm s.e.m.). Statistical analyses of interdiluent differences within methods of estimation.

\begin{tabular}{|c|c|c|c|c|c|c|}
\hline \multirow[t]{2}{*}{$\begin{array}{l}\text { Thawing } \\
\text { diluent }\end{array}$} & \multirow[t]{2}{*}{$\begin{array}{l}\text { Method of } \\
\text { estimation }\end{array}$} & \multicolumn{2}{|c|}{$\begin{array}{l}\text { Percentages of spermatozoa } \\
\text { with }\end{array}$} & \multicolumn{3}{|c|}{ Level of significance } \\
\hline & & NA & SDA & & NA & SDA \\
\hline $\mathbf{A}$ & F.s. & $11 \pm 0.9$ & $8 \pm 1.6$ & $A-C$ & $* \star *$ & $\star \star \star *$ \\
\hline C & F.s. & $5 \pm 0.6$ & $18 \pm 1.4$ & $\mathbf{A}-\mathbf{D}$ & ns & $\star \star \star$ \\
\hline D & F.s. & $11 \pm 1.3$ & $19 \pm 1.9$ & $C \curvearrowleft D$ & 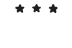 & ns \\
\hline A & B. & $13 \pm 1.3$ & $21 \pm 1.3$ & $A-C$ & ns & $\star \star \star$ \\
\hline C & B. & $10 \pm 1.2$ & $25 \pm 1.2$ & $\mathbf{A}-\mathbf{D}$ & * & ns \\
\hline D & B. & $16 \pm 1.2$ & $22 \pm 1.4$ & $\mathrm{C} \sim \mathrm{D}$ & $* \star \star$ & $\star$ \\
\hline
\end{tabular}

sponse to caffeine stimulation after 3 hrs.' storage thus indicated that the decrease in motility during storage was due to two phenomena dependent on the thawing diluent. In seminal plasma and OLEP the decrease appeared to be connected with inhibition of motility in spermatozoa still alive. In samples thawed in isotonic glucose solution the immotile spermatozoa did not respond to caffeine stimulation; the immotile spermatozoa seemed to be dead.

\section{Acrosome morphology}

The different types of acrosomal altenations recorded, as well as a sperm cell with a normal acrosome, are illustrated in Figs. 1-4. The results of the light microscopical investigations are summarized in Tables $2 \mathrm{~A}$ and $2 \mathrm{~B}$ together with statistical analyses of differences between the methods of estimation and of differences between the thawing diluents.

From Table $2 \mathrm{~A}$ it is obvious that the method of estimation influenced the results. The percentages of normal acrosomes (NA) as well as the percentages of severely damaged acrosomes (SDA) were highest after staining with Bryan's triple stain. After thawing in seminal plasma the differences between the methods in percentages of spermatozoa with SDA were significant or highly significant for all boars. This might be due to an increased incidence of artifacts in the acrosomes following staining with Bryan's triple stain. However, after thawing in seminal plasma the agglutination of spermatozoa fixed in formol-saline makes 
the evaluation more difficult and this might be a further cause of the differences found.

Thawing in OLEP yielded the lowest percentages of spermatozoa with NA, while the lowest percentages of spermatozoa with SDA were obtained after thawing in seminal plasma (Tables $2 \mathrm{~A}$, $2 \mathrm{~B})$. The results thus indicate that thawing in seminal plasma caused less alterations in the acrosomes than did thawing in OLEP. Thawing in isotonic glucose solution yielded percentages of NA close to those obtained after thawing in seminal plasma and percentages of SDA similar to those obtained after thawing in OLEP (in formol-saline) or in seminal plasma (Bryan staining). Thawing in isotonic glucose solution thus caused less acrosomal alterations than thawing in OLEP.

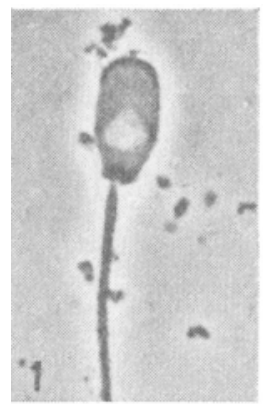

Figures $1-4$
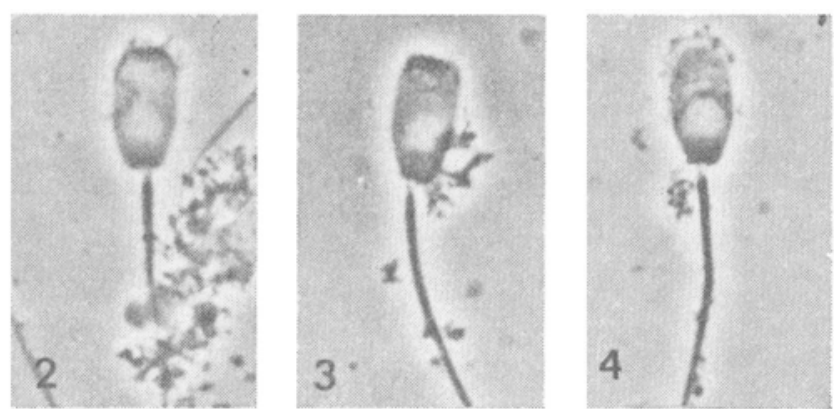

are phase-contrast photomicrographs of frozenthawed boar spermatozoa.

Fig u r e 1. Sperm cell with normal acrosome (NA). $\times 900$.

Figure 2. Sperm cell with damaged acrosome (DA). The apical ridge is swollen and uneven. $\times 900$.

Figure 3. Sperm cell with damaged acrosome (DA). The apical ridge is swollen and the anterior border forms a tongue-like segment folding over the nucleus. $\times 900$.

Figur e 4. Sperm cell with severely damaged acrosome (SDA). The apical ridge is disintegrated with loss of acrosomal substance. The equatorial segment is still intact.

\section{Ultrastructural investigation}

The results of the ultrastructural investigation are illustrated by Figs. 5-8. All spermatozoa examined showed some degree of ultrastructural alteration as compared with freshly ejaculated or epididymal spermatozoa treated in the same way. The mildest type of alteration seen was a slight swelling of the acrosome margin (Fig. 5). The mast common type of alteration was a 
transfer of the substance of the acrosomal ridge to a position over the flat surface of the sperm head. Within this substance numerous membrane-bounded vesicles were present (Fig. 6). Some spermatozoa showed severe damage, with the acrosome markedly swollen and empty-looking, except for the equatorial segment. The plasma membranes had disappeared from the heads of these spermatozoa (Fig. 7).

The tails generally looked normal; some middle-pieces showed many mitochondria with a swollen matrix (Fig. 8). The plasma membrane of most spermatozoa was broken in some places, but this was a consistent finding also in freshly ejaculated and epididymal spermatozoa treated in the same way.

The ultrastructural alterations found could not be related to any particular thawing diluent. Neither were there any visible differences between the two ejaculates examined.

\section{ASAT release}

The influence of the thawing diluents on release of ASAT is summarized in Table 3 together with statistical analysis of interdiluent differences.

$\mathrm{T}$ a b l e 3. Release of ASAT (mU/10 spermatozoa) from deep frozen spermatozoa from four boars after thawing in three diluents. Statistical analysis of interdiluent differences within ejaculates.

\begin{tabular}{|c|c|c|c|}
\hline Boar & $\begin{array}{l}\text { Thawing } \\
\text { diluent }\end{array}$ & $\begin{array}{l}\text { ASAT release } \\
\text { mean } \pm \text { s.e.m. }\end{array}$ & $\begin{array}{l}\text { Level of significance } \\
\text { for interdiluent diff. }\end{array}$ \\
\hline 388 & A & $475 \pm 93$ & $\mathrm{~A}-\mathrm{C}^{*}$ \\
\hline 388 & $\mathbf{C}$ & $172 \pm 45$ & $\mathrm{C}-\mathrm{D} * \star \star *$ \\
\hline 388 & D & $812 \pm 77$ & $\mathbf{A}-\mathbf{D}^{\star *}$ \\
\hline 172 & $\mathbf{A}$ & $293 \pm 68$ & $\mathrm{~A}-\mathrm{C}$ n.s. \\
\hline 172 & C & $280 \pm 77$ & $\mathrm{C}_{-}-\mathrm{D}^{* \star *}$ \\
\hline 172 & D & $938 \pm 85$ & $\mathbf{A}-\mathbf{D}^{* * *}$ \\
\hline 1164 & $\mathbf{A}$ & $176 \pm 70$ & $\mathrm{~A}-\mathrm{C}$ n.s. \\
\hline 1164 & C & $316 \pm 82$ & $\mathrm{C}-\mathrm{D}$ ** \\
\hline 1164 & D & $728 \pm 56$ & $\mathbf{A}-\mathbf{D}^{\star \star}$ \\
\hline 966 & $\mathbf{A}$ & $348 \pm 94$ & A-C, n.s. \\
\hline 966 & C & $564 \pm 179$ & C $-\mathrm{D}$ n.s. \\
\hline 966 & D & $838 \pm 95$ & $A-D^{\star \star \star *}$ \\
\hline All & $\mathbf{A}$ & $323 \pm 43$ & A-C n.s. \\
\hline \multirow[t]{2}{*}{ Boars } & C & $333 \pm 51$ & $\mathrm{C}-\mathrm{D}^{\star \star \star}$ \\
\hline & D & $829 \pm 1.01$ & $\mathbf{A}-\mathbf{D}^{\star \star *}$ \\
\hline
\end{tabular}


In the pooled material no difference was observed between seminal plasma and OLEP. On the other hand thawing in isotonic glucose solution produced highly significantly increased ASAT release in comparison to seminal plasma and OLEP.

Except for the ejaculates from boar 388 no significant differences in extracellular ASAT activity were found between samples thawed in seminal plasma or in OLEP. The most striking result of this analysis was the large amounts of ASAT released in samples thawed in isotonic glucose solution. Only in the ejaculates from boar 966 did the ASAT activity not significantly differ between samples thawed in OLEP and in isotonic glucose solution. Between seminal plasma and isotonic glucose solution the differences were always significant or highly significant. The measurement of extracellular ASAT activity thus indicated differences in the influence of isotonic glucose solution and the other two thawing diluents.

\section{DISCUSSION}

Frozen boar spermatozoa thawed in isotonic glucose solution yield poor fertility, while spermatozoa thawed in seminal plasma or OLEP yield good fentility (Larsson \& Einarsson 1976). In this study the influence of the same three thawing diluents on vitality, acrosome morphology, including ultrastructure, and enzyme release of frozen-thawed boar spermatozoa was investigated.

The light microscopic evaluations of acrosome morphology indicated differences in influence of the three thawing diluents. The thermoresistance test, the response to caffeine stimulation during the thermoresistance test and the measurement of extra-

Figur e s 5-8 are electron micrographs of boar spermatozoa (their head in saggital section).

Figure 5. The acrosome is normal except for a slightly swollen margin. $\times 25,000$.

Figure 6. The most frequent type of acrosomal damage; the substance of the margin is displaced and contains numerous membraneous vesicles. $\times 25,000$.

F i g u r e 7. The "seriously damaged acrosome" is swollen and almost empty, except for the equatorial segment. The plasma membrane has disappeared over the acrosome. $\times 25,000$.

Figur e 8. Part of mitochondrial sheath, longitudinal section. Some mitochondria are swollen with a light matrix. $\times 40,000$. 
cellular ASAT activity disclosed obvious differences between isotonic glucose solution and the other two thawing diluents. Regarding the influence of the thawing diluents, the acrosomal alterations do not seem to be connected with the damage reflected by the thermoresistance test and by the measurement of extracellular ASAT activity.

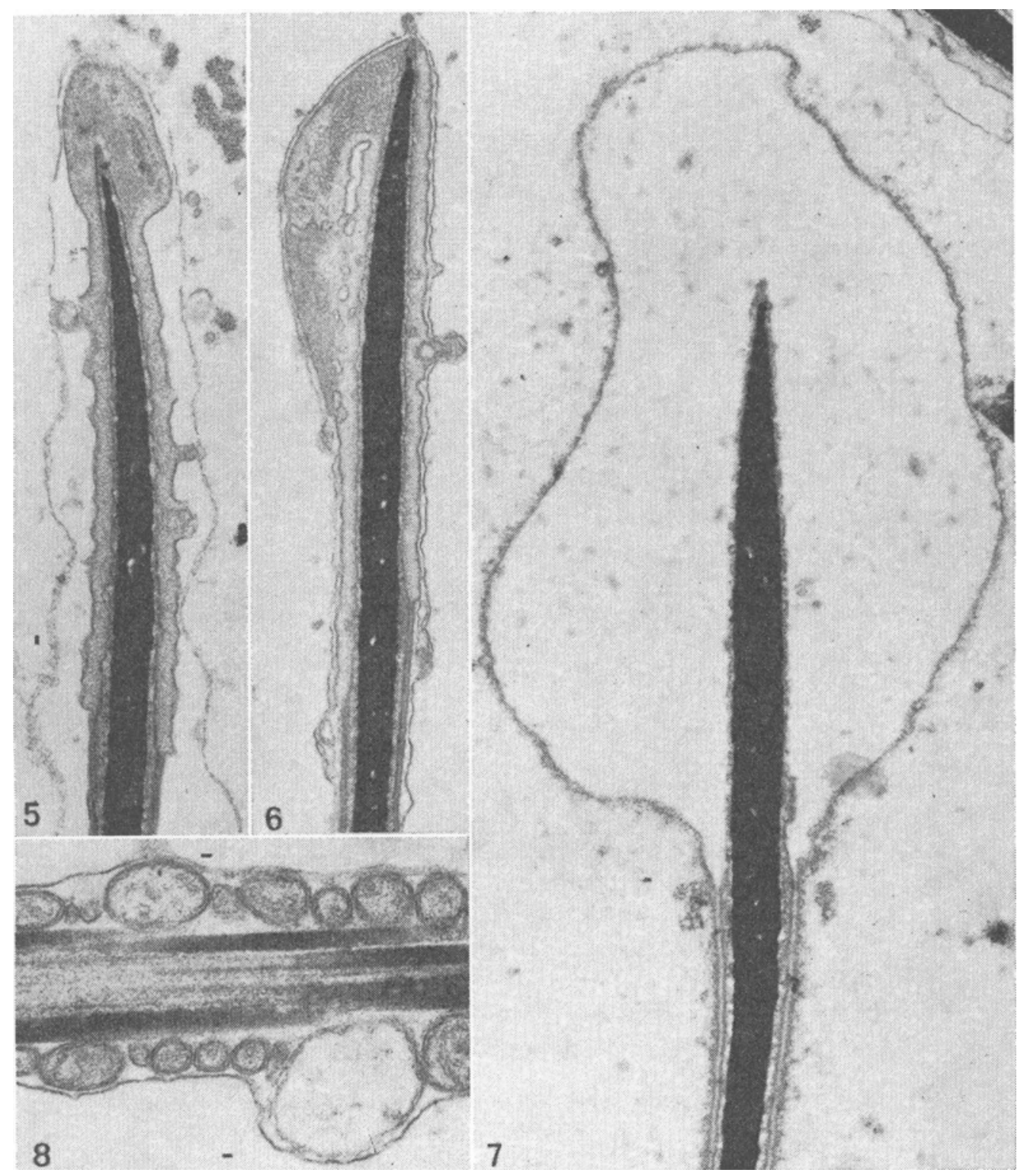


The results of the thermoresistance test, demonstrating a marked decrease of sperm motility during the incubation period, are in agreement with previous studies (Einarsson et al. 1972, 1974, Westendorf et al. 1975). The extremely poor motility of spermatozoa thawed in isotonic glucose solution at the end of the thermoresistance test might be related to the poor fertility of spermatozoa thawed in this diluent. Einarsson \& Viring (1973) showed that spermatozoa with shont in vitro survival also disappeared rapidly from the genital tract of inseminated female swine. In agreement with this observation the poor motility in all samples from boar 966 at the end of the thermoresistance test might indicate low fertility of frozen-thawed spermatozoa from this boar.

Differences in frequency of spermatozoa with normal acrosomes and of spermatozoa with severely damaged acrosomes were observed among the thawing diluents when investigated by phase-contrast or light microscopy (Table 2B). The differences between the two methods might be caused by an increased incidence of artifacts after Bryan staining, which caused the higher percentages of SDA found with this method (Table 2A). The higher percentages of normal acrosomes recorded in Bryanstained smears, compared with formol-saline fixed samples, might be due to a condensation of acrosomal substance in swollen acrosomes caused by the drying of the smears.

The ultrastructural investigation showed similar acrosomal alterations regardless of thawing diluent. All spermatozoa examined had some degree of ultrastructural alteration of the acrosome. The mildest alteration, a swelling of the acrosome, was apparently not detectable with light microscopic methods. The most frequent type of acrosomal alteration, a vesiculation of displaced acrosomal substance, is similar to changes reported by Jones (1973a) in ageing spermatozoa. However, in the present material the loss of the outer acrosomal membrane reported by Jones (1973a) was not seen. Breakage of the plasma membrane was seen in all samples studied. This is a familiar effect of processing spermatozoa for electron microscopy, and boar spermatozoa have been reported to be comparatively sensitive in this respect (Jones $1973 \mathrm{~b}$ ).

The results of the investigations on acrosome morphology indicate that the freezing-thawing procedure per se was followed by structural changes of the acrosome. The thawing diluents in- 
fluenced the frequency of the alterations, but not their character. Good fertility of frozen boar spermatozoa has been related to high percentages of spermatozoa with normal acrosomes (Pursel \& Johnson 1975, Westendorf et al. 1975). In the present study, higher percentages of spermatozoa with normal acrosomes were found after thawing in isotonic glucose solution than after thawing in OLEP, although the influence of these diluents on fertility is the reverse (Larsson \& Einarsson 1976). This indicates that acrosomal alterations (c.f. the definition of damaged acrosomes, DA) following freezing and thawing are not necessarily connected with low fertility. However, the present material does not permit an analysis of the relationship between acrosome morphology and fertility within thawing diluents. Such an analysis would finally prove whether a relationship exists or not. The analogy to spontaneous cases when subfertility or sterility in boars has been related to acrosomal abnormalities is less valid since, in these cases, the defects appeared already during spermateliosis (Bane \& Nicander 1966).

High extracellular activity of GOT (ASAT) was previously reported after thawing of frozen boar spermatozoa in isotonic glucose solution (Larsson \& Einarsson 1975). The results of the present investigation are similar. The increased leakage of ASAT, an enzyme mainly of mitochondrial origin, was not accompanied by structural changes of the mitochondria visualized in the ultrastructural investigation that could explain the difference between isotonic glucose solution and the other two thawing diluents. The measurement of extracellular enzyme activity thus seems to be a more sensitive indicator of membrane damage than an ultrastructural investigation.

Acconding to the results of the present investigation the thermoresistance test and the measurement of ASAT release are sensitive indicatons of sperm damage during freezing and thawing. These tests might therefore be useful for indication of variations in sensitivity of the spermatozoa to the freezingthawing procedure. 


\section{REFERENCES}

Andersen, $K .:$ Morphological abnormalities in the acrosome and nucleus of boar spermatozoa. Nord. Vet.-Med. 1974, 26, 215-218.

Bane, A.: Acrosomal abnormality associated with sterility in boar. Proc. IVth Int. Congr. Anim. Reprod., The Hague 1961, 4, 810 817.

Bane, A. \& L. Nicander: Electron and light microscopical studies on spermateliosis in a boar with acrosome abnormalities. J. Reprod. Fertil. 1966, 11, 133-138.

Boehnke, H. J., R. Hahn, K.-H. Hillman, H. Treu, W. Lorrmann and H. F. Zoder: Zur Tiefgefrierung von Ebersperma. 3 Mitteilung: Weitere Labor- und Besamungsversuche unter Verwendung von TEST und TESNaK-Verdünner sowie verschiedenen Auftaumethoden. (3. Communication: Deepfreezing of boar semen; Laboratory experiments and further field trials using TEST and TESNaK-diluent and different thawing methods). Dtsch. tierärztl. Wschr. 1974, 81, 336-339.

Brown, K. I., B. G. Crabo, E. F. Graham \& M. M. Pace: Some factors affecting loss of intracellular enzymes from spermatozoa. Cryobiology $1971,8,220-224$.

Bryan, J. H. D.: An eosin-fast green-naphtol yellow mixture for differential staining of cytologic components in mammalian spermatozoa. Stain Technol. 1970, 45, 231-236.

The Committee on Enzymes of the Scandinavian Society for Clinical Chemistry and Clinical Physiology: Recommended methods for the determination of four enzymes in blood. Scand. J. clin. Lab. Invest. 1974, 33, 291-306.

Crabo, B. \& S. Einarsson: Fertility of deep frozen boar spermatozoa. Acta vet. scand. $1971,12,125-127$.

Crabo, B. G. \& E. F. Graham: Correlation between some laboratory methods for evaluation of boar semen after freezing. Proc. VIIth Int. Congr. Anim. Reprod., Munich 1972, II, $1639-1643$.

Crabo, B. G., R. E. Bower, K. I. Brown, E. F. Graham \& M. M. Pace: Extracellular glutamic-oxaloacetic transaminase as a measure on membrane injury in spermatozoa during treatment. In Current Problems in Fertility, Plenum Press, New York 1971, 3338.

Crabo, B. G., K. I. Brown \& E. F. Graham: Effect of some buffers on the storage and freezing of boar spermatozoa. J. Animal Sci. 1972, 35, 377-382.

Einarsson, S. \& S. Viring: Distribution of frozen-thawed spermatozoa in the reproductive tract of gilts at different time intervals after insemination. J. Reprod. Fertil. 1973, 32, 117-120.

Einarsson, S., O. Soosalu, T. Swensson \& S. Viring: On the fertility and survival of deep frozen boar spermatozoa thawed in skim milk. Acta vet. scand. 1972, 13, 446-448.

Einarsson, S., M. Holtman, O. Soosalu, T. Swensson \& S. Viring: Studies on the fertility and survival of deepfrozen boar spermatozoa thawed in four different diluents. Zuchthygiene 1974, 9, 40-45. 
Garbers, D. L., N. L. First, S. K. Gorman \& H. A. Lordy: The effects of cyclic nucleotide phosphodiesterase inhibitors on ejaculated porcine spermatozoan metabolism. Biol. Reprod. 1973, 8, 599606.

Graham, E. F. \& B. G. Crabo: Some factors influencing the freezing of boar spermatozoa. Proc. VIIth Int. Congr. Anim. Reprod., Munich 1972, II, 1627-1632.

Graham, E. F. \& M. M. Pace: Some biochemical changes in spermatozoa due to freezing. Cryobiology 1967, 4, 75-84.

Hancock, J. L.: The morphology of boar spermatozoa. J. roy. micr. Soc. $1957,76,89-97$.

Healey, $P$.: Effect of freezing on the ultrastructure of the spermatozoa of some domestic animals. J. Reprod. Fertil. 1969, 18, 21-27.

Hillman, K.-H. \& H. Treu: Zur Tiefgefrierung von Ebersperma 1. Mitteilung: Darstellung und Messung morphologischer und enzymatischer Veränderungen beim Tiefgefrieren von Eberspermien. (Deep freezing of boar semen: Demonstration and estimation of morphological and enzyme changes of deep-frozen boar semen). Zuchthygiene 1973, 8, 105-112.

Holst, S. J.: Sterility in boars. Nord. Vet.-Med. 1949, 1, 87-120.

Jones, R. C.: Changes occurring in the head of boar spermatozoa: Vesiculation or vacuolation of the acrosome? J. Reprod. Fertil. 1973a, 33, 113-118.

Jones, $R$. C.: The plasma membrane of ram, boar and bull spermatozoa. J. Reprod. Fertil. 1973b, 33, 17.9-183.

Larsson, $K$. \& S. Einarsson: Fertility and post-thawing characteristics of deep frozen boar spermatozoa. Andrologia 1975, 7, 25-30.

Larsson, $K$. \& S. Einarsson: Fertility of deep frozen boar spermatozoa. Influence of thawing diluents and of boars. Acta vet. scand. $1976,17,43-62$.

Polge, C.: Artificial insemination in pigs. Vet. Rec. 1956, 68, 62-76.

Pursel, V. G. \& L. A. Johnson: Freezing of boar spermatozoa: Fertilizing capacity with concentrated semen and a new thawing procedure. J. Animal Sci. 1975, 40, 99-102.

Pursel, V. G., L. A. Johnson \& G. B. Rampaceck: Acrosome morphology of boar spermatozoa incubated before cold shock. J. Animal Sci. 1972, 34, 278-283.

Pursel, V. G., L. A. Johnson \& L. L. Schulman: Effect of dilution seminal plasma and incubation period on cold shock susceptibility of boar spermatozoa. J. Animal Sci. 1973, 37, 528-531.

Romeny, E., K.-H. Hillman \& L. Richter: Zur Tiefgefrierung von Ebersamen. 4. Mitteilung: Labor- und Besamungsversuche mit dem Hülsenberg Verdünner IV. (Deep freezing of boar semen. 4. Communication: Laboratory experiments and inseminations with frozen boar semen using the extender Hülsenberg IV). Dtsch. tierärztl. Wschr. 1974, 81, 353-354.

Snedecor, G. W.: Statistical Methods. Ames, Iowa 1966, 5th. Ed.

Westendorf, P., L. Richter \& H. Treu: Zur Tiefgefrierung von Ebersperma: Labor- und Besamungsergebnisse mit dem Hülsenberger 
Pailletten-Verfahren. (Deep freezing of boar semen: Laboratory findings and insemination results with the "Hülsenberger Pailletten" technique). Dtsch. tierärztl. Wschr. 1975, 82, 261-267. Wilmut, I. \& C. Polge: The fertilizing capacity of boar semen stored in the presence of glycerol at 20,5 and $-79^{\circ} \mathrm{C}$. J. Reprod. Fertil. $1974,38,105-113$.

Yasuda, Y. \& I. Tanimura: Scanning electron microscopy of boar spermatozoa before and after frozen-thawed treatment. Int. J. Fertil. 1974, 19, 149-158.

\section{SAMMANFATTNING}

Vitalitet, akrosommorfologi, ultrastruktur och enzymfrisättning hos djupfrysta-upptinade galtspermier.

Föreliggande undersökning utfördes för att studera effekterna av djupfrysning och upptining på galtspermier. Trettioen ejakulat från 4 galtar undersöktes efter upptining $i$ vardera av tre olika tiningsmedier (spermaplasma från galt, OLEP, isoton glykoslösning).

Från varje ejakulat tinades $1 \times 10^{9}$ spermier $i$ vardera tiningsmediet. Varje prov undersöktes med en thermoresistenstest. Under denna test stimulerades spermiemotiliteten med coffein 30 minuter och 3 timmar efter upptining. Vidare undersöktes de tinade spermiernas akrosommorfologi och frisättningen av ASAT från spermierna. Ett ejakulat från var och en av de mest använda galtarna undersöktes med elektronmikroskopi efter upptining $i$ vart och ett av tiningsmedierna.

Skillnader i tiningsmediernas effekt konstaterades mellan isoton glykoslösning och de andra tiningsmedierna med thermoresistenstesten, effekten av coffein stimulering och i mängden frisatt ASAT. Tiningsmedierna påverkade också akrosommorfologien men något samband mellan akrosomförändringarna och de skador som påverkat utgången av thermoresistenstesten och ASAT frisättningen syntes ej föreligga.

Den elektronmikroskopiska undersökningen visade att samtliga undersökta spermier i något avseende förändrats i jämförelse med färska galtspermier som preparerats på samma sätt. Dessa förändringar kunde ej relateras till något av de använda tiningsmedierna.

Av de utförda laboratorietesterna synes thermoresistenstesten och ASAT frisättningen vara känsliga indikatorer på skador hos spermierna orsakade av frysning och upptining. Dessa tester kan vara indikatorer på variationer $\mathrm{i}$ känslighet hos spermierna för djupfrysnings-upptinings processen.

(Received February 17, 1976).

Reprints may be requested from: K. Larsson, the Department of Obstetrics and Gynaecology, Veterinary College, S-10405 Stockholm 50, Sweden. 